\title{
Benzothiadiazole[1,2-b:4,3-b']dithiophene, a new ladder-type multifused block: Synthesis and photovoltaic application
}

\author{
Shuangqiang $\mathrm{Hu}^{\mathrm{a}, \mathrm{b}, 1}$, Xichang Bao ${ }^{\mathrm{b}, 1}$, Zhitian Liu ${ }^{\mathrm{a}, *}$, Ting Wang ${ }^{\mathrm{b}}$, Zhengkun Du ${ }^{\mathrm{b}}$, \\ Shuguang Wen ${ }^{\mathrm{b}}$, Ning Wang ${ }^{\mathrm{b}}$, Liangliang Han ${ }^{\mathrm{b}}$, Renqiang Yang ${ }^{\mathrm{b}, *}$ \\ ${ }^{a}$ School of Material Science and Engineering, Wuhan Institute of Technology, Wuhan 430073, China \\ ${ }^{\mathrm{b}}$ CAS Key Laboratory of Bio-based Materials, Qingdao Institute of Bioenergy and Bioprocess Technology, Chinese Academy of Sciences, Qingdao 266101, China
}

\section{A R T I C L E I N F O}

\section{Article history:}

Received 30 June 2014

Received in revised form 23 September 2014

Accepted 3 October 2014

Available online 18 October 2014

\section{Keywords:}

Benzothiadiazole derivative

Tetracyclic compound

Donor-acceptor systems

Polymers

Solar cells

\begin{abstract}
A B S T R A C T
A new fused building block benzothiadiazole[1,2-b:4,3- $\left.b^{\prime}\right]$ dithiophene (BTDT) was prepared by covalently locking thiophene unit on both sides of benzothiadiazole (BT). On the basis of this building block, a series of conjugated copolymers containing homopolymer (P1) or electron-rich comonomers such as carbazole (P2), benzodithiophene (P3 and P4) and thiophene (P5) were obtained. All polymers have good solubility in common organic solvents. The thermal, optical, electrochemical and photovoltaic properties of the polymers were investigated systematically. The thiophene units, which were covalently fastened to the BT moiety, enlarged the planarization of the polymer backbone and thus induced stronger intermolecular $\pi-\pi$ interaction, meanwhile, decreased the electron-withdrawing ability of the BT unit. The device based on P3:PC ${ }_{71} \mathrm{BM}$ exhibited a high open-circuit voltage $\left(V_{\mathrm{OC}}\right)$ of $0.96 \mathrm{~V}$ and moderate power conversion efficiency (PCE) of $2.16 \%$.
\end{abstract}

(c) 2014 Elsevier B.V. All rights reserved.

\section{Introduction}

In recent years, great efforts have devoted to the bulk heterojunction (BHJ) polymer solar cells (PSCs) due to their enormous advantages such as light weight, low fabrication cost, mechanical flexibility, and easy manufacturing $[1,2]$. Thus, significant progress has been made through modified interfacial layers [3,4], engineered device architectures [57], optimized film morphologies [8,9], and design and synthesis of new active materials [10-13]. The power conversion efficiencies (PCEs) of the PSCs over 9\% have been reported $[14,15]$. However, the efficiency still needs to be improved for commercial application, and more intensive research should be required to further enhance the device

\footnotetext{
* Corresponding authors.

E-mail addresses: psztliu@mail.wit.edu.cn (Z. Liu), yangrq@qibebt.ac. Cn (R. Yang).

1 These authors contributed equally to this work.
}

performance [16]. One of the key points to improve the PCE is design and synthesis of high-efficient conjugated polymer materials as donor materials in the active layer [17-19]. Lots of widely accepted guidelines have been found [20-22]. Among them, an important strategy is to maximize the $\pi$-orbital overlap by building fused-ring system. For instance, covalently fastening adjacent aromatic units, the polymer could have enhanced effective $\pi$-conjugation, lower bandgap, and strong light-harvesting, which induce $\pi-\pi$ stacking and facilitate the charge transport by intermolecular hopping [23-26]. Therefore, fused-ring building blocks are widely used in synthesis of conjugated polymers, such as naphtho[2,3-b:6,7- $\left.d^{\prime}\right]$ dithiophene (NDT) [27], thienyl-phenylene-thienylene-phenylene-thienyl (TPTPT) [28], indaceno dithiophene (IDTT) [29], naphtho[1,2-c:5,6-c]bis[1,2,5]-thiadiazole (NT) [30,31]. Cheng et al. reported a multifused DTPBT unit (Scheme 1) [32], which was prepared by covalently fastening adjacent electron-rich donor (thieno[3,2-b]pyrrole) and electron-deficient acceptor 
(BT). The monomer was used to construct D-A polymers by copolymerizing with different donor units. However, the PCE of the PSCs was not very high, they thought probably because the electron donating effect of nitrogen atoms reduced the electron-deficiency of the $\mathbf{B T}$, and thus weakened the intramolecular charge transfer (ICT) along the polymer backbones. In order to better understand this point, we designed and synthesized a fused-ring building block benzothiadiazole[1,2-b:4,3- $b^{\prime}$ ]dithiophene (BTDT, Scheme 1) through covalently locking thiophene units on both sides of BT unit. The design could eliminate the influence of nitrogen atom, which could make the polymer's optical absorption red shift and has a better photovoltaic performance. 2-Ethylhexyl-thiophene units were attached to both sides of the BTDT building blocks to improve the solubility of the monomer, since the bis-bromination of BTDT substantially decreased the solubility in common solvents. On the basis of this building block, homopolymer (P1) and a series of conjugated copolymers were designed and synthesized, where monomer 7 (Scheme 3) coupled with different donor unit car-

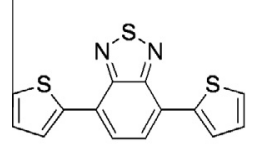

DTBT



DTPBT

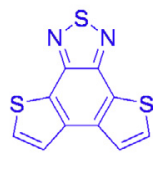

BTDT
Scheme 1. Chemical structures of nonfused DTBT, fused DTPBT and BTDT units. bazole (P2), benzo[1,2-b:4,5- $\left.b^{\prime}\right]$ dithiophene (P3 and P4), and bithiophene (P5), respectively (Scheme 2). The electrondonating ability of the donor unit increased gradually [26]. The thermal, photophysical and electrochemical properties of the polymers have been characterized and the effect of covalently fastening thiophene units was discussed carefully. Finally, Photovoltaic performance based on the polymers was evaluated.

\section{Experimental}

\subsection{Materials}

Unless stated otherwise, starting materials were obtained from Aldrich or Acros and were used without further purification. THF and toluene were distilled from sodium and benzophenone as indicator under nitrogen prior to use.

\subsection{Characterization}

${ }^{1} \mathrm{H}$ and ${ }^{13} \mathrm{C}$ NMR spectra were recorded on a Bruker Avance III 600 (600 MHz). UV-vis absorption spectra were recorded at room temperature using a Lambda 25 spectrophotometer. Molecular weight and polydispersity of the polymers were determined by gel permeation chromatography analysis (GPC, ELEOS System) with a polystyrene standard calibration (THF as the eluent). Thermogravimetric analysis (TGA) was performed by a STA-409 at a heating rate of $10^{\circ} \mathrm{C} \mathrm{min}^{-1}$ under nitrogen at atmospheric pressure.

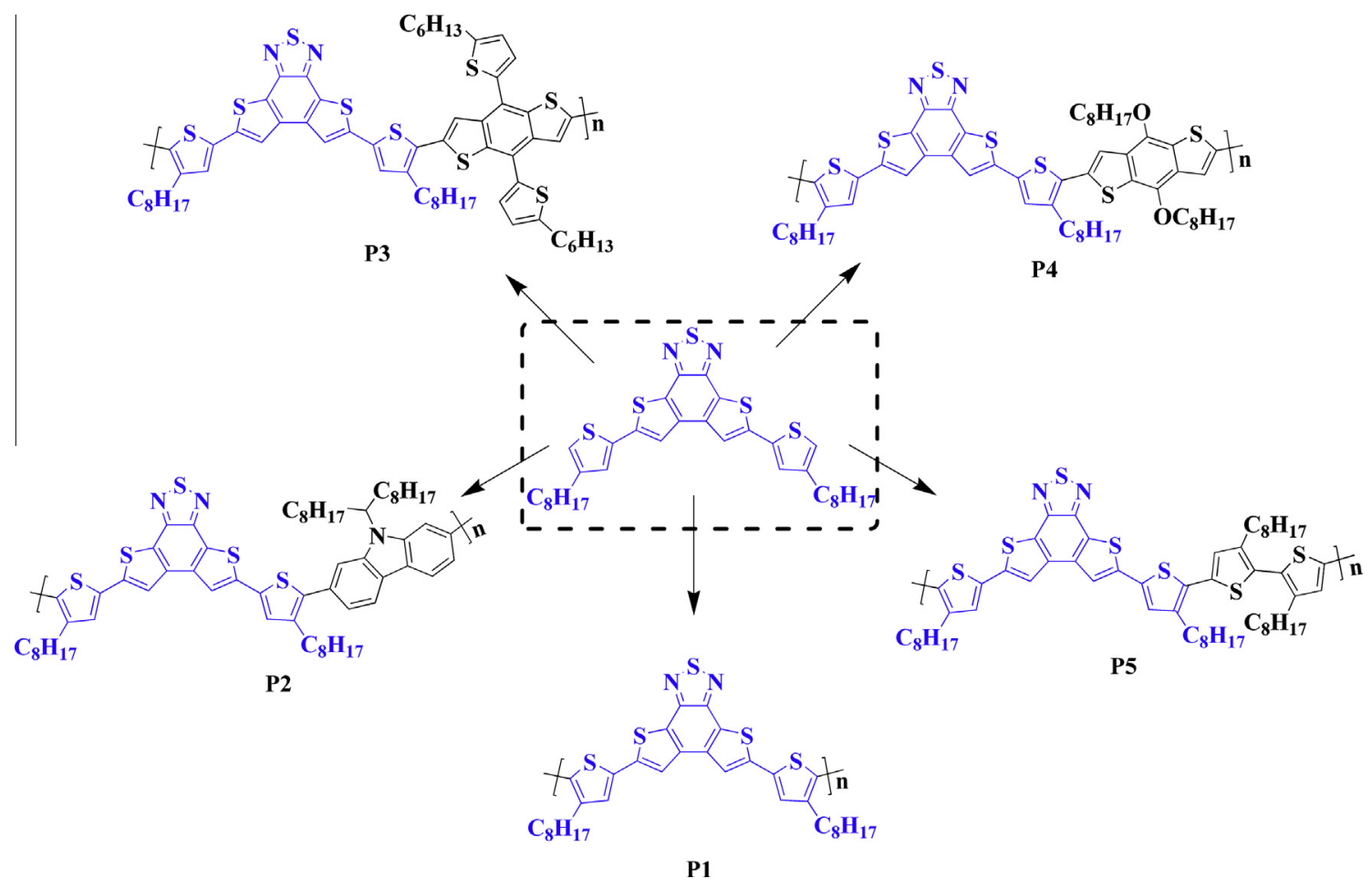

Scheme 2. Chemical structures of conjugated polymers based on BTDT. 

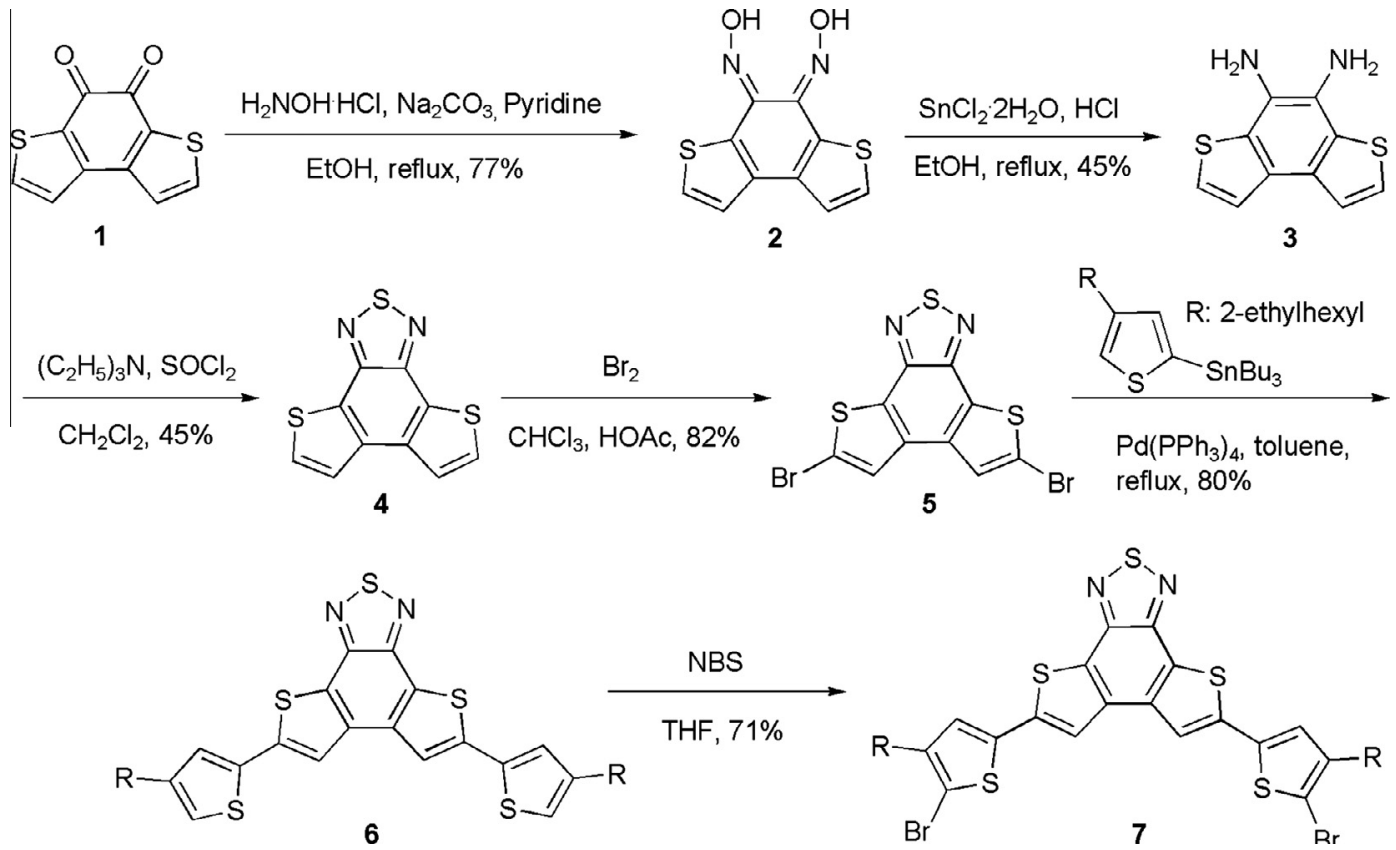

Scheme 3. Synthetic routes of the monomers.

Electrochemical cyclic voltammetry measurements were carried out using a CHI660D electrochemical workstation equipped with a glass carbon working electrode, a saturated calomel electrode as the reference, and a Pt sheet as counter electrode. The measurements were done in anhydrous acetonitrile with tetrabutylammonium hexafluorophosphate $(0.1 \mathrm{M})$ as the supporting electrolyte under an argon atmosphere at a scan rate of $100 \mathrm{mV} / \mathrm{s}$. The potential of the saturated calomel reference electrode was internally calibrated using the ferrocene/ferrocenium redox couple (Fc/Fc+).

\subsection{Fabrication and characterization of $\mathrm{BHJ}$ devices}

ITO coated glass substrates were ultrasonically cleaned sequentially with detergent, water, acetone and isopropyl alcohol. A thin layer $(30 \mathrm{~nm})$ of poly(3,4-ethylenedioxythiophene):poly(styrenesulfonate) (PEDOT:PSS, Baytron PVP A1 4083, Germany) was spin-coated on the ITO coated glass and baked at $150{ }^{\circ} \mathrm{C}$ for $30 \mathrm{~min}$. The blend solution of polymer: $\mathrm{PC}_{61} \mathrm{BM}$ or polymer: $\mathrm{PC}_{71} \mathrm{BM}$ (American Dye Sources Inc.) were dissolved in chlorobenzene $(C B)$ in a weight ratio of $1: 1$ and whole concentration of $20 \mathrm{mg} / \mathrm{ml}$. The blend solutions were stirred overnight in glovebox. The active layer was spin-coated on PEDOT:PSS modified ITO coated glass and annealed on a hotplate at $120^{\circ} \mathrm{C}$ for $10 \mathrm{~min}$. The samples were then loaded into a thermal evaporator for cathode deposition. Subsequently, $1 \mathrm{~nm} \mathrm{LiF}$ and $100 \mathrm{~nm}$ Al were thermal evaporated under $4.0 \times 10^{-4} \mathrm{~Pa}$. The active area of device defined by shadow mask is $0.1 \mathrm{~cm}^{2}$. The current density-voltage $(J-V)$ characteristics were recorded with a Keithley 2420 source measurement unit under simulated $100 \mathrm{~mW} / \mathrm{cm}^{2}$ (AM $1.5 \mathrm{G}$ ) irradiation from a Newport solar simulator. Light intensity was cali- brated with a standard silicon solar cell. External quantum efficiencies (EQE) of solar cell were analyzed by certified Newport incident photon conversion efficiency (IPCE) measurement system.

\subsection{Synthesis of compounds}

\subsubsection{Synthesis of compound 2}

A mixture of $660 \mathrm{mg}$ ( $3 \mathrm{mmol}$ ) of compound 1 and $477 \mathrm{mg}$ (4.5 mmol) $\mathrm{Na}_{2} \mathrm{CO}_{3}$ was dissolved in $10 \mathrm{~mL}$ pyridine and $40 \mathrm{~mL}$ ethanol and heated to reflux. $\mathrm{NH}_{2} \mathrm{OH} \mathrm{HCl}$ (730 $\mathrm{mg}, 3.5 \mathrm{mmol}$ ) in ethanol was added dropwise and the reaction mixture was then refluxed for $5 \mathrm{~h}$. After completion of the reaction, the mixture was cooled to room temperature and the solvent was evaporated under reduced pressure and the residue was suspended in $60 \mathrm{~mL}$ water at $80^{\circ} \mathrm{C}$ for $3 \mathrm{~h}$. The product was isolated by filtration, extensively washed with water and dried in a vacuum (red powder, $0.576 \mathrm{~g}, 77 \%$ ). ${ }^{1} \mathrm{H}$ NMR $(600 \mathrm{MHz}$, DMSO-d6): $\delta 12.89$ (s, 2H), 7.82 (d, $J=6.0 \mathrm{~Hz}, 2 \mathrm{H}$ ), 7.62 $(\mathrm{d}, J=6.0 \mathrm{~Hz}, 2 \mathrm{H})$.

\subsubsection{Synthesis of compound 3}

To a solution of compound $2(0.576 \mathrm{~g}, 2.3 \mathrm{mmol})$ in $40 \mathrm{~mL}$ ethanol at $0{ }^{\circ} \mathrm{C}$, a solution of $\mathrm{SnCl}_{2} \cdot 2 \mathrm{H}_{2} \mathrm{O}(5.226 \mathrm{~g}$, $23 \mathrm{mmol}$ ) in $10 \mathrm{~mL} \mathrm{HCl}$ conc. was added in one portion. The reaction mixture was refluxed for $3 \mathrm{~h}$, cooled to $0^{\circ} \mathrm{C}$ and filtered. The filter cake was washed with water and suspended in $50 \mathrm{~mL}$ saturated aqueous $\mathrm{NaHCO}_{3}$ and $50 \mathrm{~mL}$ methyl tert-butyl ether (TBME). The organic phase was separated and washed with brine. Finally, evaporation the solvent afforded a beige powder $(0.224 \mathrm{~g}, 45 \%) .{ }^{1} \mathrm{H}$ NMR (600 MHz, $\mathrm{CDCl}_{3}$ ): $\delta 7.62$ (d, $J=5.4 \mathrm{~Hz}, 2 \mathrm{H}$ ), 7.33 (d, $J=5.4 \mathrm{~Hz}, 2 \mathrm{H}), 3.65(\mathrm{~s}, 4 \mathrm{H})$. 


\subsubsection{Synthesis of compound 4}

To a solution of compound $3(0.22 \mathrm{~g}, 1 \mathrm{mmol})$ and

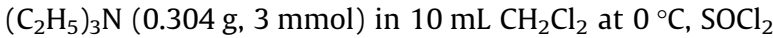
$(0.357 \mathrm{~g}, 3 \mathrm{mmol})$ was added dropwise and the reaction mixture was stirred for $1 \mathrm{~h}$ at room temperature and $5 \mathrm{~h}$ at reflux. The reaction was quenched by added $10 \mathrm{~mL}$ water and stirred for $30 \mathrm{~min}$. The organic phase was separated and washed with water and dried over anhydrous $\mathrm{MgSO}_{4}$. The crude product was purified by column chromatography on silica gel $\left(\mathrm{CH}_{2} \mathrm{Cl}_{2}\right.$ /petroleum ether $\left.=1: 3\right)$ to give 4 as a yellow solid $(99.1 \mathrm{mg}, 45 \%) .{ }^{1} \mathrm{H}$ NMR $\left(600 \mathrm{MHz}, \mathrm{CDCl}_{3}\right): \delta 7.74(\mathrm{~d}, J=5.4 \mathrm{~Hz}, 2 \mathrm{H}), 7.71$ (d, $J=5.4 \mathrm{~Hz}, 2 \mathrm{H})$.

\subsubsection{Synthesis of compound 5}

Compound $4(124 \mathrm{mg}, 0.5 \mathrm{mmol})$ was dissolved in $\mathrm{CHCl}_{3}(10 \mathrm{~mL})$ and $\mathrm{CH}_{3} \mathrm{COOH}(10 \mathrm{~mL})$ and cooled to $0{ }^{\circ} \mathrm{C}$. A solution of $\mathrm{Br}_{2}$ (322 mg, $2 \mathrm{mmol}$ ) diluted 1:10 (vol.) in $\mathrm{CHCl}_{3}$ was slowly added. After that the reaction mixture was heated to reflux for $12 \mathrm{~h}$. The mixture was diluted with aqueous $\mathrm{Na}_{2} \mathrm{~S}_{2} \mathrm{O}_{3}$ solution when cooling to room temperature. Subsequently, the mixture was separated and washed with saturated aqueous $\mathrm{NaHCO}_{3}$ solution and brine. Then dried over $\mathrm{MgSO}_{4}$, filtered and concentrated under vacuum, and the solid product was recrystallized from DMF to give 5 as a yellow solid (164.4 mg, 82\%). ${ }^{1} \mathrm{H}$ NMR $\left(600 \mathrm{MHz}, \mathrm{CDCl}_{3}\right): \delta 7.65(\mathrm{~s}, 2 \mathrm{H})$.

\subsubsection{Synthesis of compound 6}

Compound 5 (245 mg, $0.603 \mathrm{mmol})$ and tributyl(4-(2ethylhexyl)thiophen-2-yl)stannane (765 mg, $1.575 \mathrm{mmol}$ ) were added to $40 \mathrm{~mL}$ toluene in a $100 \mathrm{~mL}$ three-neck flask and purged with $\mathrm{N}_{2}$ for 30 min. Tetrakis(triphenylphosphine)-palladium $(0)$ ( $35 \mathrm{mg}, 0.03 \mathrm{mmol}$ ) was added to the mixture and refluxed for $48 \mathrm{~h}$. After the mixture was cooled to room temperature, the solvent was evaporated under reduced pressure, and then dissolved in $50 \mathrm{~mL}$ acetic ether and extensively washed with water and brine. The organic phase was separated and dried over anhydrous $\mathrm{MgSO}_{4}$. After removal of the solvent by vacuum evaporation, the residue was purified by column chromatography on silica gel $\left(\mathrm{CH}_{2} \mathrm{Cl}_{2}\right.$ /petroleum ether $\left.=1: 10\right)$ to give $\mathbf{6}$ as a yellow solid (308 mg, 80\%). ${ }^{1} \mathrm{H}$ NMR (600 MHz, $\mathrm{CDCl}_{3}$ ): $\delta 7.53(\mathrm{~s}, 2 \mathrm{H}), 7.17(\mathrm{~s}, 2 \mathrm{H}), 6.92(\mathrm{~s}, 2 \mathrm{H}), 2.58(\mathrm{~d}, J=0.6 \mathrm{~Hz}$, $4 \mathrm{H}), 1.68-1.63(\mathrm{~m}, 2 \mathrm{H}), 1.41-1.30(\mathrm{~m}, 16 \mathrm{H}), 0.96-0.93$ $(\mathrm{m}, 12 \mathrm{H}) .{ }^{13} \mathrm{C}$ NMR $\left(150 \mathrm{MHz}, \mathrm{CDCl}_{3}\right): \delta 149.2,143.3$, $141.4,136.5,136.0,127.2,126.0,121.7,118.2,40.3,34.6$, $32.5,28.9,25.7,23.1,14.2,10.9$.

\subsubsection{Synthesis of compound 7}

$\mathrm{N}$-Bromosuccinimide ( $55 \mathrm{mg}, 0.308 \mathrm{mmol}$ ) was added portion-wise to a solution of compound 6 ( $89 \mathrm{mg}$, $0.14 \mathrm{mmol}$ ) in $30 \mathrm{~mL}$ of THF at room temperature. After the mixture was stirred for $12 \mathrm{~h}, \mathrm{NaHCO}_{3}$ solution was added, and the mixture was extracted with dichloromethane. The organic layer was washed with water and brine and then dried over anhydrous $\mathrm{MgSO}_{4}$. The solvent was removed by vacuum evaporation, and the residue was purified by column chromatography on silica gel $\left(\mathrm{CH}_{2} \mathrm{Cl}_{2} /\right.$ petroleum ether $=1: 10$ ), then dissolved in $1 \mathrm{~mL}$ ether and added portion-wise to $100 \mathrm{~mL}$ methanol and deposited
$24 \mathrm{~h}$, filtered and concentrated under vacuum to give $\mathbf{7}$ as a yellow solid (79 mg, 71\%). ${ }^{1} \mathrm{H}$ NMR (600 $\mathrm{MHz}, \mathrm{CDCl}_{3}$ ): $\delta$ $7.50(\mathrm{~s}, 2 \mathrm{H}), 7.02(\mathrm{~s}, 2 \mathrm{H}), 2.52(\mathrm{~d}, J=0.6 \mathrm{~Hz}, 4 \mathrm{H}), 1.68-$ $1.65(\mathrm{~m}, 2 \mathrm{H}), 1.40-1.30(\mathrm{~m}, 16 \mathrm{H}), 0.94-0.91(\mathrm{~m}, 12 \mathrm{H}) .{ }^{13} \mathrm{C}$ NMR $\left(150 \mathrm{MHz}, \mathrm{CDCl}_{3}\right): \delta 149.2,142.7,140.4,136.4$, 135.7, 126.7, 126.3, 118.4, 110.5, 40.0, 33.9, 32.5, 28.8, $25.7,23.1,14.2,10.9$.

\subsection{Synthesis of the polymers}

The polymers were prepared by a similar procedure. To a Schlenk flask was introduced compound 7 (278 mg, $0.35 \mathrm{mmol})$, the corresponding other monomer $(0.35 \mathrm{mmol})$, anhydrous toluene $\left(8 \mathrm{~mL}\right.$ ) (and $2 \mathrm{~mL} \mathrm{~K}_{2} \mathrm{CO}_{3}$ aqueous solution ( $2 \mathrm{M}$ ) in Suzuki coupling reaction). The solution was flushed with nitrogen for $5 \mathrm{~min}$, then $\mathrm{Pd}\left(\mathrm{PPh}_{3}\right)_{4}$ (12 mg, $3 \mathrm{~mol} \%$ ) was added into the solution. After the resulting flask was degassed thrice via a freezepump-thaw cycle, the reactants were heated up to $110^{\circ} \mathrm{C}$ for $72 \mathrm{~h}$. Then, the reaction was cooled to room temperature and added into methanol dropwise. The precipitate was filtered and dried, then purified by column chromatography on silica gel (chloroform) to give the products.

Polymer P1. Yellow solid, yield 71\%. ${ }^{1} \mathrm{H}$ NMR (600 MHz, $\mathrm{CDCl}_{3}$ ): $\delta 7.64$ (br, 4H), 2.56 (br, 4H), 2.0-0.7 (br, 30H). Anal. Calcd. for $\left(\mathrm{C}_{34} \mathrm{H}_{38} \mathrm{~N}_{2} \mathrm{~S}_{5}\right)_{\mathrm{n}}: \mathrm{C}, 64.31 ; \mathrm{H}, 6.03 ; \mathrm{N}, 4.41$; S, 25.25. Found: C, 64.75; H, 6.12; N, 4.37; S, 24.76. GPC: $\mathrm{Mn}=18.4 \mathrm{kDa}$, PDI $=1.53$.

Polymer P2. Yellow solid, yield 75\%. ${ }^{1} \mathrm{H}$ NMR $(600 \mathrm{MHz}$, $\mathrm{CDCl}_{3}$ ): $\delta 7.72$ (br, 2H), $7.55(\mathrm{br}, 2 \mathrm{H}), 7.32$ (br, 6H), 4.62 (br, $1 \mathrm{H}), 2.77$ (br, 4H), 2.5-0.7 (br, 64H). Anal. Calcd. for $\left(\mathrm{C}_{63} \mathrm{H}_{79} \mathrm{~N}_{3} \mathrm{~S}_{5}\right)_{\mathrm{n}}$ : C, 72.85; H, 7.67; N, 4.05; S, 15.44. Found: C, 72.63; H, 7.72; N, 4.15; S, 15.50. GPC: $\mathrm{Mn}=37.1 \mathrm{kDa}$, PDI $=1.35$.

Polymer P3. Red solid, yield 84\%. ${ }^{1} \mathrm{H}$ NMR $(600 \mathrm{MHz}$ $\mathrm{CDCl}_{3}$ ): $\delta 7.28$ (br, 10H), 2.54 (br, 8H), 2.0-0.7 (br, 52H). Anal. Calcd. for $\left(\mathrm{C}_{64} \mathrm{H}_{70} \mathrm{~N}_{2} \mathrm{~S}_{9}\right)_{\mathrm{n}}: \mathrm{C}, 66.50 ; \mathrm{H}, 6.10 ; \mathrm{N}, 2.42$; S, 24.97. Found: C, 66.75; H, 6.17; N, 2.34; S, 24.74. GPC: $\mathrm{Mn}=13.7 \mathrm{kDa}, \mathrm{PDI}=4.62$.

Polymer P4. Red solid, yield 70\%. ${ }^{1} \mathrm{H}$ NMR $(600 \mathrm{MHz}$ $\left.\mathrm{CDCl}_{3}\right): \delta 7.28$ (br, 6H), 7.10 (br, 2H), 4.13 (br, 2H), 2.83 (br, 4H), 2.5-0.7 (br, 60H). Anal. Calcd. for $\left(\mathrm{C}_{60} \mathrm{H}_{74} \mathrm{~N}_{2} \mathrm{O}_{2} \mathrm{~S}_{7}\right)_{\mathrm{n}}$ : C, 66.74; H, 6.91; N, 2.59; S, 20.79. Found: C, 66.35; H 7.03; N, 2.42; S, 20.93. GPC: $\mathrm{Mn}=34.2 \mathrm{kDa}, \mathrm{PDI}=1.63$.

Polymer P5. Yellow solid, yield 80\%. ${ }^{1} \mathrm{H}$ NMR $(600 \mathrm{MHz}$, $\left.\mathrm{CDCl}_{3}\right): \delta 7.47(\mathrm{br}, 6 \mathrm{H}), 2.51(\mathrm{br}, 8 \mathrm{H}), 2.0-0.6$ (br, 60H). Anal. Calcd. for $\left(\mathrm{C}_{58} \mathrm{H}_{74} \mathrm{~N}_{2} \mathrm{~S}_{7}\right)_{n}$ : C, 68.05; H, 7.29; N, 2.74; S, 21.93. Found: C, 68.27; H, 7.23; N, 2.67; S, 21.83. GPC: $\mathrm{Mn}=9.7 \mathrm{kDa}, \mathrm{PDI}=3.17$

\section{Results and discussion}

\subsection{Synthesis and characterization}

The synthetic routes of the monomers and polymers are outlined in Schemes 2 and 3. Benzo[1,2-b:4,3-b']dithiophen-4,5-quinone (1) was synthesized according to the literature [33], then oxidation with hydroxylamine to afford a benzo[1,2-b:4,3-b']dithiophen-4,5-dioxime (2). Reduction reaction of $\mathbf{2}$ with tin (II) chloride dihydrate gave 
benzo[1,2-b:4,3-b']dithiophen-4,5-diamine (3). The benzothiadiazole[1,2-b:4,3-b']dithiophene (4) were synthesized through thionyl chloride cyclization. Bromination of 4 with bromine gave the monomer $\mathbf{5}$. Stille coupling reaction of $\mathbf{5}$ with tributyl(4-(2-ethylhexyl)thiophen-2-yl)stannane afforded 6, which was brominated with N-bromosuccinimide (NBS) to afford monomer $\mathbf{7}$.

Copolymer P2 was synthesized through Suzuki coupling reaction of the di-bromide monomer 7 with 2,7-bis (4', $4^{\prime}, 5^{\prime}, 5^{\prime}$-tetramethyl-1', $3^{\prime}, 2^{\prime}$-dioxaborolan-2'-yl)-N-9' heptadecanylcarbazole. Polymer P1 and P3-P5 were synthesized thr-ough Stille coupling reaction of the dibromide monomer 7 with hexamethylditin, 1,1'-[4,8-bis[5(2-hexane)-2-thienyl]benzo[1,2-b:4,5- $\left.b^{\prime}\right]$ dithiophene-2, 6-diyl]bis(1,1,1-trimethyl)stannane, 2,6-bis(trimethyltin)4,8-bis-(2-ethylhexyloxy)benz-o[1,2-b:4,5- $\left.\mathrm{b}^{\prime}\right]$ dithiophene, 3,3'-bis(2-ethylhexyl)-2,2'-bithiophene-5,5'-diyl-bis-trimethylstannane, respectively. The polymerization reactions were undergone $\mathrm{i}-\mathrm{n}$ toluene for $72 \mathrm{~h}$ at refluxed temperature. The structures of the polymers were characterized by NMR. All polymers have excellent solubility in common organic solvents, such as chloroform (CF), tetrahydrofuran (THF), chlorobenzene (CB).

Molecular weights of the polymers were determined by gel permeation chromatography (GPC) using polystyrene standards as calibrant, showing the number-average molecular weight $\left(M_{\mathrm{n}}\right)$ ranging from $9.7 \mathrm{kDa}$ of P5 to $37 \mathrm{kDa}$ of P2. The polydispersity index (PDI) varied from 1.35 to 4.62 (Table 1 ). Thermal properties of all polymers were characterized by thermogravimetric analysis (TGA) under nitrogen atmosphere (Fig. 1). As shown in Table 1 and Fig. 1, all polymers show excellent thermal stabilities, and the decomposition temperatures (Td) are in the range of $398-454{ }^{\circ} \mathrm{C}$. Obviously, the thermal stabilities of the BTDT-based polymers are adequate for their applications in PSCs and other optoelectronic devices.

\subsection{Optical properties}

Fig. 2a and b shows the ultraviolet-visible (UV-vis) absorption spectra of the polymers in dilute chloroform solutions and in thin films on quartz substrates, respectively. We also do the concentration-dependent measurement to choose of $\mathbf{P 2}$ randomly. The corresponding absorption properties are summarized in Table 2. All of the copolymers show two absorption peaks, which is a common feature of D-A type copolymers. The absorption

Table 1

Molecular weights and thermal properties of the polymers.

\begin{tabular}{llllll}
\hline & Yield (\%) & $M_{\mathrm{n}}{ }^{\mathrm{a}}$ & $M_{\mathrm{w}}{ }^{\mathrm{a}}$ & $M_{\mathrm{w}} / M_{\mathrm{n}}{ }^{\mathrm{a}}$ & $T_{\mathrm{d}}{ }^{\mathrm{b}}\left({ }^{\circ} \mathrm{C}\right)$ \\
\hline P1 & 71 & 18,370 & 28,120 & 1.53 & 398 \\
P2 & 75 & 37,140 & 50,150 & 1.35 & 454 \\
P3 & 84 & 13,750 & 63,490 & 4.62 & 443 \\
P4 & 70 & 34,230 & 55,670 & 1.63 & 429 \\
P5 & 80 & 9740 & 30,876 & 3.17 & 437 \\
\hline
\end{tabular}

a Number-average molecular weight $\left(M_{\mathrm{n}}\right)$, weight-average molecular weight $\left(M_{\mathrm{w}}\right)$, and polydispersity index $\left(M_{\mathrm{w}} / M_{\mathrm{n}}\right)$ determined by means of GPC with THF as eluent on the basis of polystyrene calibration.

b Temperature at $5 \%$ weight loss estimated using TGA under $\mathrm{N}_{2}$.

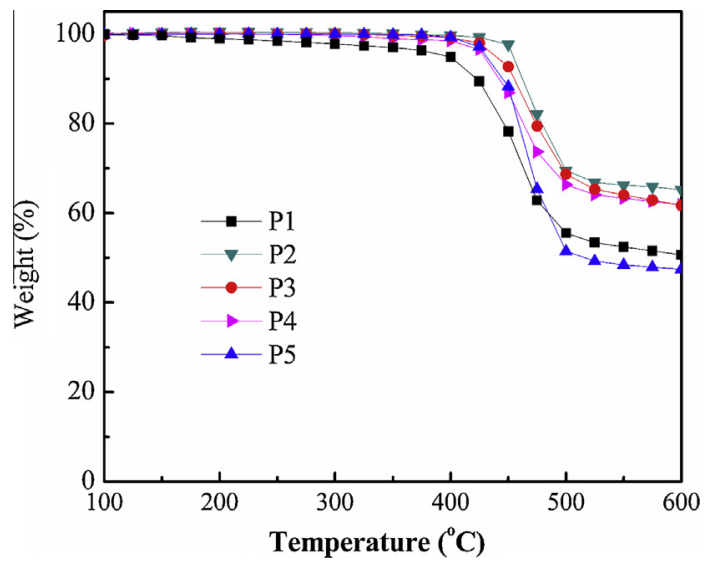

Fig. 1. TGA curves of the polymers.

peaks at short wavelength originate from $\pi-\pi^{*}$ transition of the tetracyclic units, while the absorption peaks at long wavelength could be attributed to the strong ICT interaction between the electron-rich moieties and electron-deficient segments [34]. Interestingly, the absorption curves of the polymers in films are generally similar to those of in solutions, and there is no distinct red-shift observed (Fig. 2 and Table 2). It could be due to weak $\pi-\pi$ interactions in films and even in solutions. For homopolymer P1, the absorption maxima and edge are at $363 \mathrm{~nm}$ and $506 \mathrm{~nm}$ in film, while the absorption maxima of P2 is at $378 \mathrm{~nm}$ and the edge at a similar level, and the absorption edge of P5 in film slightly red-shifts to $528 \mathrm{~nm}$. P3 and P4 show an obvious red-shifted (83 and $69 \mathrm{~nm}$ ) of the
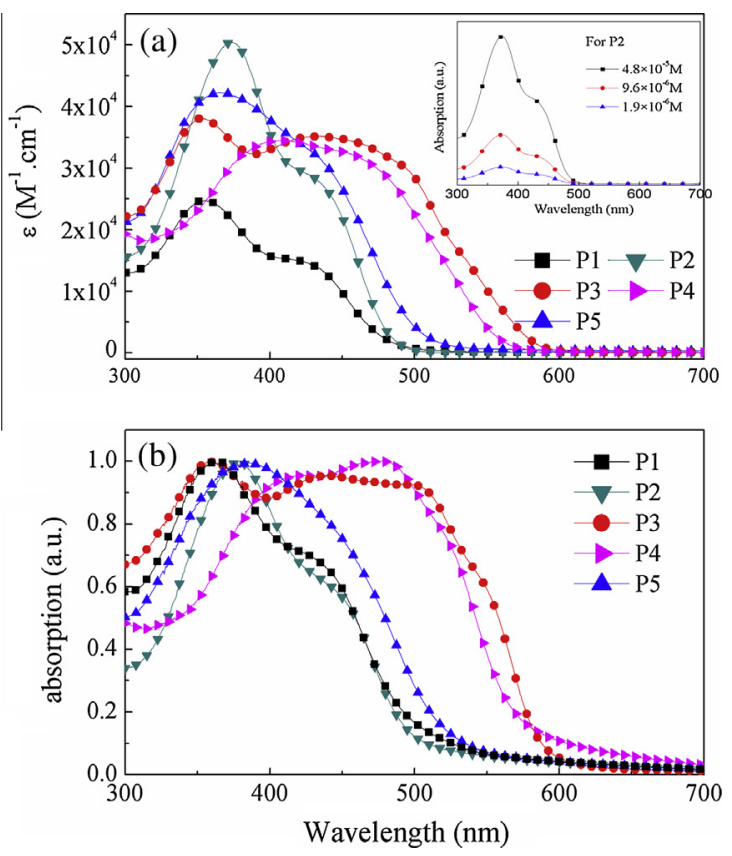

Fig. 2. Absorption spectra of P1-P5 in $\mathrm{CHCl}_{3}$ solutions (a) and in thin films (b). The inset figure is concentration dependent measurement for P2. 
Table 2

Optical and electrochemical properties of the polymers.

\begin{tabular}{|c|c|c|c|c|c|c|c|c|}
\hline \multirow[t]{2}{*}{ Polymers } & \multicolumn{3}{|l|}{ Solution } & \multicolumn{2}{|l|}{ Film } & \multirow[t]{2}{*}{$E_{\mathrm{ox}}^{\text {onset }}(\mathrm{V})$} & \multirow[t]{2}{*}{$\mathrm{HOMO}^{\mathrm{a}}(\mathrm{eV})$} & \multirow[t]{2}{*}{ LUMO $^{\mathrm{b}}(\mathrm{eV})$} \\
\hline & $\lambda \max (\mathrm{nm})$ & ionset (nm) & $\lambda \max (\mathrm{nm})$ & ionset (nm) & Egopt (eV) & & & \\
\hline P1 & 358 & 485 & 363 & 506 & 2.45 & 1.27 & -5.69 & -3.24 \\
\hline P2 & 376 & 486 & 378 & 502 & 2.47 & 1.18 & -5.60 & -3.13 \\
\hline P3 & 356 & 594 & 360 & 589 & 2.10 & 1.12 & -5.54 & -3.44 \\
\hline P4 & $406(452)$ & 562 & $423(477)$ & 575 & 2.16 & 1.06 & -5.48 & -3.32 \\
\hline P5 & 370 & 501 & 385 & 528 & 2.35 & 1.13 & -5.55 & -3.20 \\
\hline
\end{tabular}

a Estimated from the onset oxidation, assuming the absolute energy level of ferrocene/ferrocenium to be $4.8 \mathrm{eV}$ below vacuum

b Estimated by addition of the absorption onset to the HOMO.

absorption edge to 589 and $575 \mathrm{~nm}$, respectively. The absorption maxima of the copolymers have no relationship with the electron donating ability of the donor units. These polymers exhibited blue-shifted absorption spectra relative to DTBT-based and DTPBT-based polymers. In detail, the absorption edge of $\mathbf{P 2}$ is $502 \mathrm{~nm}$ in film, however, the polymer PCDTBT [35] is $660 \mathrm{~nm}$ and PCDTPBT [32] is $570 \mathrm{~nm}$. The results were quite opposite to what we had expected. Firstly, it could be due to the reduced electronwithdrawing ability of the BT unit seriously, which is caused by the thiophene rings. Secondly, the two thiophenes of the BTDT are cross-conjugated, result in no clear conjugation pathway through the acceptor. For all polymers, the intensity of $\pi-\pi^{*}$ transition absorption band is stronger than the ICT band. A similar phenomenon has been found in polymer PIDT-phanQ [36]. When the two phenyl rings connected by a single bond between the ortho positions, the intensity of $\pi-\pi^{*}$ transition absorption band has grown larger than the ICT band. The absorption of PIDT-phanQ in film shows $30 \mathrm{~nm}$ red-shift compared to that in chloroform, this is due to the extended conjugation length of the phenanthrenequinoxaline unit on PIDTphanQ, even though the reduced electron-withdrawing ability of the quinoxaline unit. Regarding the electrondonating ability of phenyl ring is much lower than that of thiophene unit, it is concluded that the electron-donating ability of thiophene unit is so strong that decreased the electron-withdrawing ability of the BT unit seriously. Thus, the monomer $\mathbf{7}$ could be a weak acceptor or a neutral monomer.

The phenomena indicated that the covalently fastening adjacent thiophene units, which have forced the structure more planar, induced stronger intermolecular $\pi-\pi$ interaction, but decreased the electron-withdrawing ability of the BT unit in the polymers seriously. Hence the photoinduced charge transfer transition from the electron-rich units to the BT unit in the BTDT-based polymers becomes difficult.

\subsection{Electrochemical properties}

Cyclic voltammetry (CV) was employed to investigate the electrochemical properties and estimate the highest occupied molecular orbital (HOMO) (Table 2 and Fig. 3). The HOMO energy levels are estimated to be -5.65 , $-5.50,-5.44,-5.41$, and $-5.50 \mathrm{eV}$ for the P1-P5, respectively (Table 2). The low-lying HOMO energy levels suggest that the polymers are oxidatively stable hole transporting materials [37,38] and also are desired in BHJ solar cells as an approach to maximize the open circuit voltage $\left(V_{\mathrm{OC}}\right)$, which is known to be related to the difference in the HOMO level of the donor polymer and LUMO level of the acceptor.

\subsection{Photovoltaic properties}

The bulk heterojunction (BHJ) solar cells based on binary blends of each BTDT-based polymer with $\mathrm{PC}_{61} \mathrm{BM}$ ( $1: 1$, optimized conditions for the polymers) with a conventional structure of ITO/PEDOT:PSS/blend film/LiF/Al were fabricated and characterized. The fabrication process is described in detail in the Experimental Section. The photovoltaic performance, including the current density $\left(J_{\mathrm{SC}}\right)$ $V_{\mathrm{OC}}$, fill factor $(\mathrm{FF})$, and PCE are summarized in Table 3. Representative current density-voltage $(J-V)$ curve of the P3: $\mathrm{PC}_{71} \mathrm{BM}$ device is shown in Fig. 4a. From Table 3, the photovoltaic performance of the homopolymer $\mathbf{P 1}$ is very poor, with a PCE of only $0.02 \%$ and a $V_{\mathrm{OC}}$ of $0.58 \mathrm{~V}$. Interestingly, the $V_{\mathrm{OC}}$ of the copolymers is very high $(0.81-1.00 \mathrm{~V})$. The FF and $J_{\text {SC }}$ are extremely low for copolymers P2 and P5. The PCE is only $0.02 \%$ and $0.09 \%$, respectively. As discussed above in optical properties (see Fig. 2b), the absorption edges of P1, P2, and P5 are at about $500 \mathrm{~nm}$ and the absorption peaks in the UV region, thus, the poor light harvesting in the visible region resulted in extremely low $J_{\mathrm{SC}}$ and PCE. For copolymers P3 and P4, the absorption edges have red-shift compared to P1, P2, and P5. The improved PCEs are ascribed to the enhancement of the $J_{\mathrm{SC}}$ for cover-

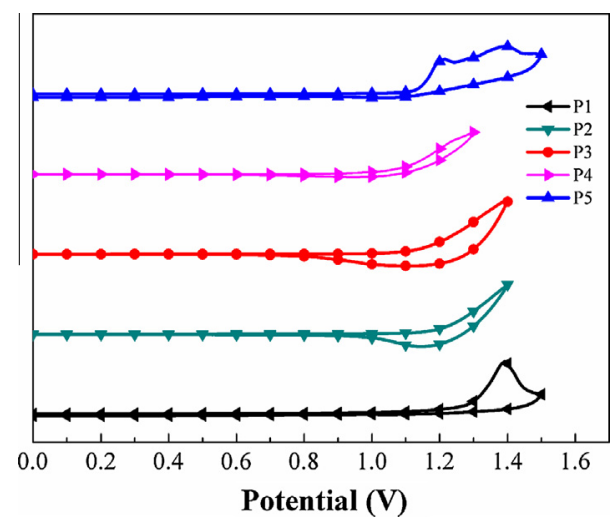

Fig. 3. Cyclic voltammograms of the polymers in thin film at a scan rate of $100 \mathrm{mV} / \mathrm{s}$. 
Table 3

Photovoltaic characteristics of the polymers.

\begin{tabular}{llllll}
\hline Active layer & Blend ratio & $J_{\mathrm{SC}}\left(\mathrm{mA} / \mathrm{cm}^{2}\right)$ & $V_{\mathrm{OC}}(\mathrm{V})$ & FF & PCE $(\%)$ \\
\hline P1:PC61BM & $1: 1$ & 0.15 & 0.58 & 0.26 & 0.02 \\
P2:PC61BM & $1: 1$ & 0.11 & 0.81 & 0.24 & 0.02 \\
P3:PC61BM & $1: 1$ & 5.45 & 0.95 & 0.37 & 1.90 \\
P4:PC61BM & $1: 1$ & 3.64 & 0.98 & 0.38 & 1.35 \\
P5:PC61BM & $1: 1$ & 0.50 & 0.82 & 0.23 & 0.09 \\
P3:PC71BM & $1: 1$ & 5.49 & 0.96 & 0.41 & 2.16 \\
P4:PC71BM & $1: 1$ & 3.98 & 1.00 & 0.39 & 1.55 \\
\hline
\end{tabular}
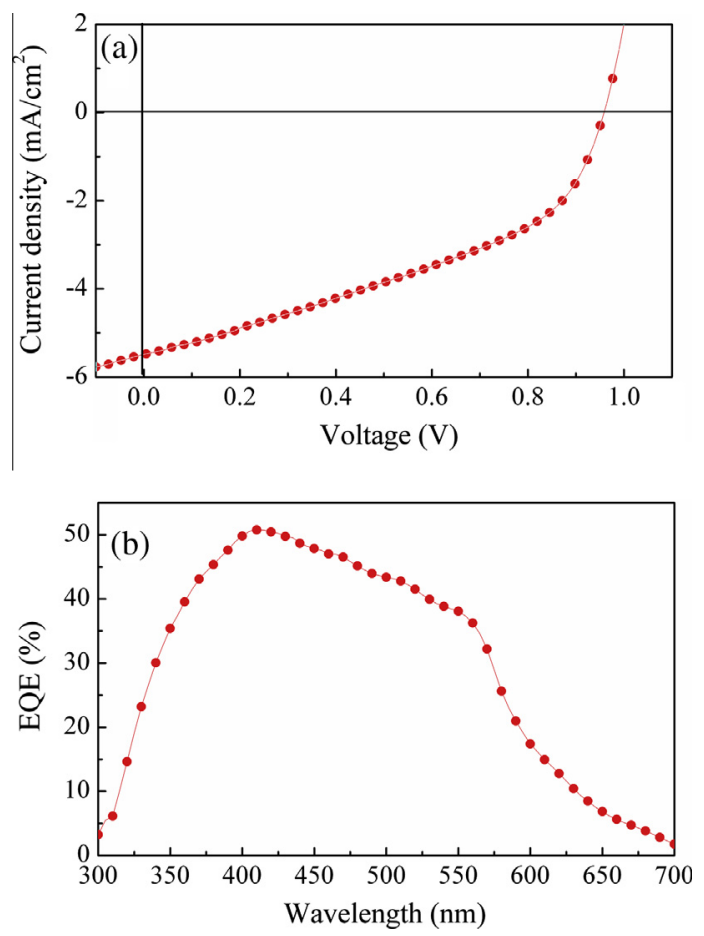

Fig. 4. $J-V$ (a) and $E Q E$ (b) curves of the PSC based on $\mathbf{P} 3 / \mathrm{PC}_{71} \mathrm{BM}$ with weight ratio of $1: 1$ under the illumination of $A M 1.5 \mathrm{G}, 100 \mathrm{~mW} / \mathrm{cm}^{2}$.

ing more fraction visible region. The devices were also prepared based on $\mathbf{P 3}$ and $\mathbf{P 4}$ blend with $\mathrm{PC}_{71} \mathrm{BM}$, respectively. The solar cells based on P3:PC ${ }_{71} \mathrm{BM}$ exhibited a $V_{\mathrm{OC}}$ of $0.96 \mathrm{~V}$, a $J_{\mathrm{SC}}$ of $5.49 \mathrm{~mA} / \mathrm{cm}^{2}$, a FF of $41 \%$ and thus a PCE of $2.16 \%$. Compared with P4: $\mathrm{PC}_{71} \mathrm{BM}$ blend $\left(V_{\mathrm{OC}}=1.00 \mathrm{~V}\right.$, $J_{\mathrm{SC}}=3.98 \mathrm{~mA} / \mathrm{cm}^{2}, \mathrm{FF}=39 \%$ and $\mathrm{PCE}=1.55 \%$ ), which is very similar to $\mathbf{P} 3$ in chemical structure, the relatively higher $J_{\mathrm{SC}}$ and FF might be due to the broad and strong absorption band and thermal stability, since the comonomer benzodithiophene (BDT) unit with two thienyl conjugated side chains plays more important role than the two corresponding alkoxy substituted copolymers [39].

Fig. 4b shows the representative external quantum efficiency (EQE) spectra of the PSC device fabricated with P3: $\mathrm{PC}_{71} \mathrm{BM}$ under monochromatic light illumination. It exhibited a broad EQE profile ranging from 300 to $700 \mathrm{~nm}$ with the maximum value of $50 \%$ at $405 \mathrm{~nm}$. This could partially explain why $\mathbf{P} \mathbf{3}: \mathrm{PC}_{71} \mathrm{BM}$ device shows the highest PCE among the series of BTDT polymers. Moreover,
The $J_{\mathrm{SC}}\left(5.51 \mathrm{~mA} / \mathrm{cm}^{2}\right)$ calculated from the integration of the EQE agrees well with the $J_{\mathrm{SC}}\left(5.49 \mathrm{~mA} / \mathrm{cm}^{2}\right)$ obtained from the $J-V$ measurements.

\section{Conclusions}

A new fused benzothiadiazole[1,2-b:4,3-b']dithiophene where two outer thiophene rings were covalently fastened on both sides of BT unit have been successfully synthesized. On the basis of this building block, a series of new conjugated copolymers have been obtained. The attaching thiophene rings to the BT structure enhanced the effective $\pi$-conjugation length and induced face-to-face $\pi$-stacking. However, it decreased the electron-withdrawing ability of the BT unit. As a result, the ICT between the donors and the acceptors was reduced greatly. Optimized photovoltaic results show that the PSC based on P3:PC ${ }_{71} \mathrm{BM}$ exhibited a PCE of $2.16 \%$, with a $J_{S C}$ of $5.49 \mathrm{~mA} / \mathrm{cm}^{2}$, a $V_{\text {OC }}$ of $0.96 \mathrm{~V}$ and a $\mathrm{FF}$ of $41 \%$. It reveals that when fastening units with different electronic properties into a coplanar fused D-A assembly, it should be taken into account the influence of their electron-donating or electron-withdrawing ability on the building blocks, adequately.

\section{Acknowledgements}

This work was supported by National Natural Science Foundation of China (21202181, 51003080, 51173199, $51211140346,51303197,61107090)$, the Ministry of Science and Technology of China (2010DFA52310), Natural Science Foundation of Hubei Province (2012FFB04705), and the Youth Science Plan for Light of the Morning Sun of Wuhan City (201271031385).

\section{References}

[1] C.J. Brabec, Sol Energy Mater. Sol. Cells 83 (2004) 273-292.

[2] H.F. Wang, Q.Q. Shi, Y.Z. Lin, H.J. Fan, P. Cheng, X.W. Zhan, Y.F. Li, D.B. Zhu, Macromolecules 44 (2011) 4213-4221.

[3] M.D. Irwin, J.D. Servaites, D.B. Buchholz, B.J. Leever, J. Liu, J.D. Emery, M. Zhang, J.H. Song, M.F. Durstock, A.J. Freeman, M.J. Bedzyk, M.C. Hersam, R.P.H. Chang, M.A. Ratner, T.J. Marks, Chem. Mater. 23 (2011) 2218-2226.

[4] L. Motiei, Y. Yao, J. Choudhury, H. Yan, T.J. Marks, M.E. Boom, A. Facchetti, J. Am. Chem. Soc. 132 (2010) 12528-12530.

[5] Y. Sun, J.H. Seo, C.J. Takacs, J. Seifter, A.J. Heeger, Adv. Mater. 23 (2011) 1679-1683.

[6] C.M. Amb, S. Chen, K.R. Graham, J. Subbiah, C.E. Small, F. So, J.R. Reynolds, J. Am. Chem. Soc. 133 (2011) 10062-10065.

[7] Y. Shi, C. Zhu, L. Wang, W. Li, K.K. Fung, N. Wang, Chem. Eur. J. 19 (2013) 282-287.

[8] W.L. Ma, C.Y. Yang, X. Gong, K. Lee, A.J. Heeger, Adv. Funct. Mater. 15 (2005) 1617-1622

[9] J. Peet, A.J. Heeger, G.C. Bazan, Acc. Chem. Res. 42 (2009) 1700-1708.

[10] P.L.T. Boudreault, A. Najari, M. Leclerc, Chem. Mater. 23 (2011) 456469.

[11] A. Facchetti, Chem. Mater. 23 (2011) 733-758.

[12] X.X. Sun, W.C. Chen, Z.K. Du, X.C. Bao, G.N. Song, K.Q. Guo, N. Wang, R.Q. Yang, Polym. Chem. 4 (2013) 1317-1322.

[13] N. Wang, X.C. Bao, C.P. Yang, J. Wang, H.Y. Woo, Z.G. Lan, W.C. Chen, R.Q. Yang, Org. Electron. 14 (2013) 682-692.

[14] Z.C. He, C.M. Zhong, S.J. Su, M. Xu, H.B. Wu, Y. Cao, Nature Photon. 6 (2012) 591-595.

[15] S.H. Liao, H.J. Jhuo, Y.S. Cheng, S.A. Chen, Adv. Mater. 25 (2013) $4766-4771$.

[16] F.C. Krebs, K. Norrman, Prog. Photovolt: Res. Appl. 15 (2007) 697712.

[17] Y.J. Cheng, S.H. Yang, C.S. Hsu, Chem. Rev. 109 (2009) 5868-5923. 
[18] O. Inganas, F. Zhang, M.R. Andersson, Acc. Chem. Res. 42 (2009) 1731-1739.

[19] Y.F. Li, Y.P. Zou, Adv. Mater. 20 (2008) 2952-2958.

[20] M.C. Scharber, D. Mühlbacher, M. Koppe, P. Denk, C. Waldauf, A.J. Heeger, C.J. Brabec, Adv. Mater. 18 (2006) 789-794.

[21] B.C. Thompson, J.M. Frechet, Angew. Chem. Int. Ed. 47 (2008) 58-77.

[22] F.A. Arroyave, C.A. Richard, J.R. Reynolds, Org. Lett. 14 (2012) 6138 6141.

[23] Y.F. Li, Acc. Chem. Res. 45 (2012) 723-733.

[24] C.-Y. Mei, L. Liang, F.-G. Zhao, J.-T. Wang, L.-F. Yu, Y.-X. Li, W.-S. Li, Macromolecules 46 (2013) 7920-7931.

[25] S. Ando, J.I. Nishida, H. Tada, Y. Inoue, S. Tokito, Y. Yamashita, J. Am. Chem. Soc. 127 (2005) 5336-5337.

[26] H.X. Zhou, L.Q. Yang, W. You, Macromolecules 45 (2012) 607-632.

[27] S.R. Sanjaykumar, S. Badgujar, C.E. Song, W.S. Shin, S.J. Moon, I.N Kang, J. Lee, S. Cho, S.K. Lee, J.C. Lee, Macromolecules 45 (2012) 6938-6945.

[28] C.H. Chen, Y.J. Cheng, C.Y. Chang, C.S. Hsu, Macromolecules 44 (2011) 8415-8424.

[29] Y.X. Xu, C.C. Chueh, H.L. Yip, F.Z. Ding, Y.X. Li, C.Z. Li, X. Li, W.C. Chen, A.K. Jen, Adv. Mater. 24 (2012) 6356-6361.
[30] I. Osaka, M. Shimawaki, H. Mori, I. Doi, E. Miyazaki, T. Koganezawa, K. Takimiya, J. Am. Chem. Soc. 134 (2012) 3498-3507.

[31] M. Wang, X.W. Hu, P. Liu, W. Li, X. Gong, F. Huang, Y. Cao, J. Am. Chem. Soc. 133 (2011) 9638-9641.

[32] Y.J. Cheng, Y.J. Ho, C.H. Chen, W.S. Kao, C.E. Wu, S.L. Hsu, C.S. Hsu, Macromolecules 45 (2012) 2690-2698.

[33] A. Meyer, E. Sigmund, F. Luppertz, G. Schnakenburg, I. Gadaczek, T. Bredow, S.S. Jester, S. Hoger, Beilstein J. Org. Chem. 6 (2010) 11801187.

[34] J. Zhang, W.Z. Cai, F. Huang, E.G. Wang, C.M. Zhong, S.J. Liu, M. Wang, C.H. Duan, T.B. Yang, Y. Cao, Macromolecules 44 (2011) 894-901.

[35] N. Blouin, A. Michaud, M. Leclerc, Adv. Mater. 19 (2007) 2295-2300.

[36] Y. Zhang, J.Y. Zou, H.L. Yip, K.S. Chen, D.F. Zeigler, Y. Sun, A.K.Y. Jen, Chem. Mater. 23 (2011) 2289-2291.

[37] H.N. Tsao, D. Cho, J.W. Andreasen, A. Rouhanipour, D.W. Breiby, W. Pisula, K. Müllen, Adv. Mater. 21 (2009) 209-212.

[38] I. Osaka, R. Zhang, G. Sauve, D.M. Smilgies, T. Kowalewski, R.D. McCullough, J. Am. Chem. Soc. 131 (2009) 2521-2529.

[39] L.J. Huo, S.Q. Zhang, X. Guo, F. Xu, Y.F. Li, J.H. Hou, Angew. Chem. Int. Ed. 50 (2011) 9697-9702. 